\title{
The Herpetofauna from Ilha Grande (Angra dos Reis, Rio de Janeiro, Brazil): updating species composition, richness, distribution and endemisms
}

\author{
Carlos Frederico Duarte Rocha ${ }^{1,4}$; Felipe Bottona da Silva Telles ${ }^{1,5}$; Davor Vrcibradic ${ }^{2}$ \& Paulo Nogueira-Costa ${ }^{3}$
}

\footnotetext{
1 Universidade do Estado do Rio de Janeiro (UERJ), Instituto de Biologia (IBRAG), Departamento de Ecologia (DECOL), Laboratório de Ecologia de Vertebrados. Rio de Janeiro, RJ, Brasil.

2 Universidade Federal do Estado do Rio de Janeiro (UNIRIO), Centro de Ciências Biológicas e da Saúde (CCBS), Instituto de Biociências (IBI0), Departamento de Zoologia. Rio de Janeiro, RJ, Brasil. ORCID: 0000-0002-6355-3441.E-mail: davor.vrcibradic@gmail.com

3 Universidade Federal do Sul e Sudeste do Pará (UNIFESSPA), Instituto de Estudos em Saúde e Biológicas (IESB), Faculdade de Ciências da Saúde e Biológicas (FACISB). Marabá, PA, Brasil. ORCID: 0000-0002-2194-7397. E-mail: nogueiracostap@gmail.com ${ }^{4}$ ORCID: 0000-0003-3000-1242. E-mail: cfdrocha@gmail.com

5 E-mail: fbottona@yahoo.com.br
}

\begin{abstract}
Ilha Grande is a large continental island (total area of 19,300 ha) situated at the southern coast of the state of Rio de Janeiro, in southeast Brazil, within the Atlantic Forest Biome. Here we provide an update to the previous knowledge of the fauna of amphibians and reptiles occurring in Ilha Grande, based on primary data from our own fieldwork and on secondary data (from institutional collections and from the literature). We report the occurrence at Ilha Grande of a total of 74 species, being 34 amphibians (all of them anurans) and 40 reptiles (27 snakes, 11 lizards, one amphisbaenian and one crocodylian). Our survey added 14 species to the herpetofaunal list of Ilha Grande (three of amphibians and eleven of reptiles) and removed one species (the amphibian (ycloramphus fuliginosus) from the previous list. The data indicated that Ilha Grande houses a considerable portion of the Atlantic Forest amphibian and reptile diversity (ca. 6\% and 19\%, respectively, of the species occurring in this biome) together with high occurrence of species endemic to this biome plus a few amphibian species endemic to this island. Illha Grande is thus an important reservoir of both biodiversity and endemism of amphibians and reptiles of the Atlantic Forest of Brazil, which highlights the importance of the conservation of the island and of its different habitats along the insular landscape.
\end{abstract}

Key-Words. Anura; Reptile; Atlantic Rain Forest; Diversity.

\section{INTRODUCTION}

Knowing the species composition occurring in an environment is a prerequisite for the approach of the knowledge of local biodiversity and biogeographical and ecological processes, as well as for mapping conservation and management plans in protected areas. For island communities this knowledge is particularly relevant so that one can select study models for species or populations that provide potential for evaluating the effects of geographical isolation on gene flow (BittencourtSilva \& Silva, 2013). Insular herpetofaunas constitute good research subjects in this sense because the local species richness and the individual abundance of organisms usually result from historical processes and from their species-specific capacity to transpose geographical barriers.

Ilha Grande is a continental island situated at the southern coast of the state of Rio de
Janeiro, in southeast Brazil. With a total area of $19,300 \mathrm{ha}$, it is the third largest island on the Brazilian coast. Like the other continental islands on the eastern Brazilian coast, Ilha Grande is inserted within the Atlantic Forest Biome, which is one of the world's biodiversity "hotspots" (Mittermeier et al., 2011). Ilha Grande represents one of the areas of the Atlantic Forest for which the knowledge on the vertebrate fauna has continually improved with time, especially since the establishment, in 1996, of a research station there: the Centro de Estudos Ambientais e Desenvolvimento Sustentável - CEADS of the Universidade do Estado do Rio de Janeiro. There are published introductory species lists for non-volant mammals (Pereira et al., 2001), bats (Esbérard et al., 2006), birds (Alves \& Vecchi, 2009), squamatan reptiles (Rocha \& van Sluys, 2006) and amphibians (Bittencourt-Silva \& Silva, 2013) occurring in that island. 


\section{MATERIALS AND METHODS}

Regarding the herpetofauna, Rocha et al. (2009) updated the previous reptile list of Rocha \& van Sluys (2006) by adding representatives of the Orders Crocodylia (one species of caiman) and Chelonia (three species of marine turtles) and three more species of Squamata (the lizards Anolis punctatus and Tropidurus torquatus and the snake Corallus hortulanus), as well as providing the first amphibian list for the area. However, no museum vouchers or photos were provided along with those lists. Later, Winck et al. (2011) gave details about the records of Anolis punctatus and Tropidurus torquatus, providing voucher numbers for both taxa. Bittencourt-Silva \& Silva (2013) compiled amphibian lists for some islands in the Angra dos Reis Bay, on the Rio de Janeiro coast, including Ilha Grande, providing voucher numbers for most records (except for Cycloramphus fuliginosus Tschudi, 1838) and adding seven species to the previous list of Rocha et al. (2009). Considering all those studies, the herpetofaunal list of Ilha Grande currently includes 32 reptiles (including sea turtles) and 32 amphibians (all of them anurans).

Since 1995 a research team from the Laboratório de Vertebrados of the Departamento de Ecologia from Universidade do Estado do Rio de Janeiro has conducted fieldwork at Ilha Grande (Rocha et al., 2009). Part of the results of those efforts have produced the herpetofaunal lists of Rocha \& van Sluys (2006) and Rocha et al. (2009). But, since the publication of these lists, the ongoing studies of our team have added more species records to the island's herpetofauna. Thus, in the present article we provide an update to the knowledge of amphibians and reptiles occurring in Ilha Grande, based on both primary and secondary data.

\section{Study area}

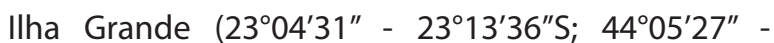
$44^{\circ} 22^{\prime} 43^{\prime \prime} \mathrm{W}$ ) lies on the southern coast of the state of Rio de Janeiro, inside Ilha Grande Bay, and belongs to the municipality of Angra dos Reis (Fig. 1). Its last connection with the continent has been around 5,100 years ago (Gama et al., 2009), and its nearest point to the mainland is currently separated from it by ca. $2 \mathrm{~km}$ of sea. It contains two terrestrial conservation units of integral protection: Parque Estadual da Ilha Grande (PEIG), with 12,052 ha, and Reserva Biológica da Praia do Sul (RBEPS), with 3,502 ha (INEA, 2013). The vegetation of Ilha Grande is part of the Atlantic Forest that covers the Serra do Mar region; the predominant type of vegetation is Dense Umbrophilous Forest, with other types of formation such as restingas (coastal habitats with sandy soils and xerophyllous vegetation), flooded forests and mangroves being also present, in a smaller scale (Alho et al., 2002; Callado et al., 2009). The climate of Ilha Grande is wet and warm, with total annual rainfall around 2,200 $\mathrm{mm}$ at the coastal lowland areas, and mean annual temperature of $21^{\circ} \mathrm{C}$ (INEA, 2013).

\section{Data collection}

To provide an update of the previous information regarding amphibian and reptile species occurring in Ilha Grande, we used primary data from our own fieldwork, supplemented with secondary data (obtained from the

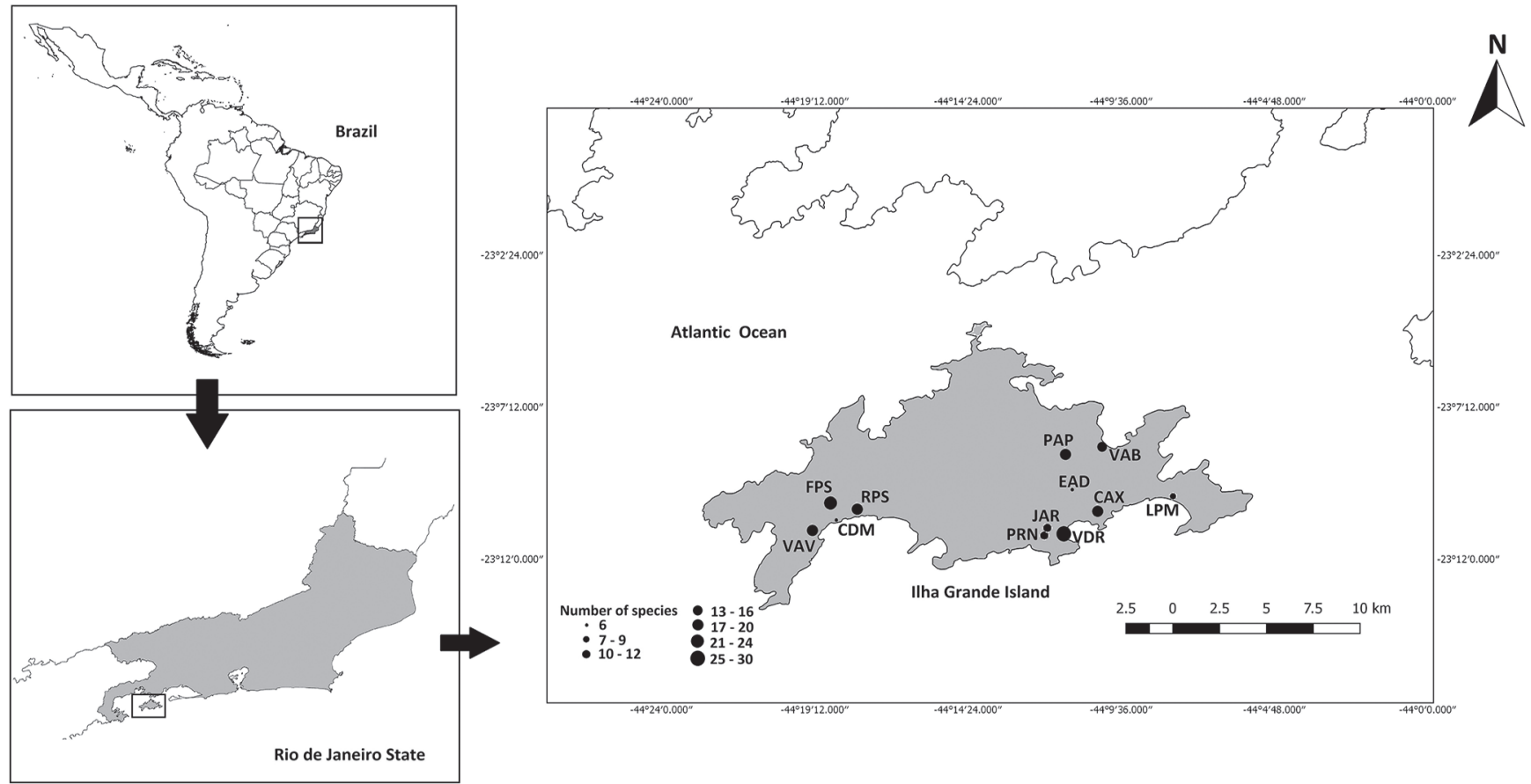

Figure 1. Image of Ilha Grande with the localities where the species were recorded, and their respective density points of species. $C A X=C a x a d a c ̧ 0$ trail; $C D M=$ Costão do Demo, RBEPS; EAD = Abraão-Dois Rios road; FPS = Forest of Praia do Sul; JAR = Jararaca trail, Dois Rios; LPM = Lopes Mendes; PAP = Pico do Papagaio; $P R N=$ Parnaioca trail; RPS = Restinga of Praia do Sul; VAB = Vila do Abraão;VAV = Vila do Aventureiro; VDR = Vila Dois Rios. 
literature and from institutional collections). Primary data were obtained from field research conducted along 21 years (1995-2015) by the Laboratório de Vertebrados do Departamento de Ecologia da Universidade do Estado do Rio de Janeiro. Most of the fieldwork has been carried out in the surroundings of the Vila Dois Rios village $\left(23^{\circ} 11^{\prime} 09^{\prime \prime} \mathrm{S}, 44^{\circ} 11^{\prime} 26^{\prime \prime} \mathrm{W}\right)$ and along forest trails leading from there to other parts of the island. But some intensive collecting has been conducted more recently (2008-2015) in other portions of the island such as Pico do Papagaio mountain, Lopes Mendes beach, and the Reserva Biológica Estadual da Praia do Sul. In the latter locality, systematic samplings were carried out between 2012 and 2014 on both restinga $\left(23^{\circ} 10^{\prime} 29^{\prime \prime} S, 44^{\circ} 17^{\prime} 56^{\prime \prime} \mathrm{W}\right)$ and umbrophilous forest $\left(23^{\circ} 10^{\prime} 25^{\prime \prime} \mathrm{S}, 44^{\circ} 18^{\prime} 45^{\prime \prime} \mathrm{W}\right)$ formations using two sampling methodologies: time-constrained (one hour per person) visual searches (Crump \& Scott Jr., 1994) and quadrat sampling (Jaeger \& Inger, 1994). Visual surveys totaled $408 \mathrm{~h}$ of sampling (204 h each on restinga and forest) and quadrat sampling was performed using 80 plots of $16 \mathrm{~m}^{2}(4 \mathrm{~m} \times 4 \mathrm{~m})$ set with nylon mesh fences on the floor of the forest and restinga (40 plots on each habitat), totaling 1,280 $\mathrm{m}^{2}$ of sampled area.

Regarding secondary data, we sought records of specimens of amphibians and reptiles from Ilha Grande deposited in herpetological collections of different institutions in the state of Rio de Janeiro, as well as published records from the literature. More specifically, we searched the catalogs of the collections of the Museu Nacional (MNRJ), the Universidade Federal Rural do Rio de Janeiro (RU), the Universidade Federal do Rio de Janeiro (ZUFRJ) and the Universidade Federal do Estado do Rio de Janeiro (UNIRIO). The site "Species Link" (www. splink.cria.org.br) was also accessed in order to verify the existence of specimens from Ilha Grande in other institutional collections, namely those of the Instituto Butantan (IBSP), of the Departamento de Zoologia de São José do Rio Preto (DZSJRP), and the Célio F.B. Haddad amphibian collection (CFBH) of the Universidade Estadual Paulista, all in the state of São Paulo. We also sought records in published articles and books in different databases for bibliographic research, such as ISI Web of Science (www. portal.isiknowledge.com), Scopus, Wilson Web, Biological Abstracts (www.periodicos.capes.gov.br) and SciELO Scientific Electronic Library Online (www.scielo.br).

In order to evaluate the occurrence of the amphibian and reptile species within Ilha Grande, we aimed to obtain the locations of occurrence on the island as accurately as possible for specimens in scientific collections and also from the literature, when such data was available. All records without identification at the specific level were disregarded, except for those involving individuals believed to belong to undescribed taxa or when such unidentified specimens were the only members of a given genus recorded at the area. The same applied for specimens identified through the taxonomic artifices "gr.", "cf." and "aff.". Nomenclature used throughout the text follows Segalla et al. (2016) and Frost (2017) for amphibians, and Costa \& Bérnils (2015) for reptiles, unless otherwise noted.

\section{RESULTS AND DISCUSSION}

The records we obtained for the non-marine herpetofauna of Ilha Grande indicated presently the occurrence of a total of 74 species, being 34 amphibians (all of them anurans) and 40 reptiles (27 snakes, 11 lizards, one amphisbaenian and one crocodilian) (Table 1). Our survey added 14 species to the herpetofaunal list of Ilha Grande, being three of amphibians (Ischnocnema bolbodactyla, Leptodactylus flavopictus and Leptodactylus latrans; Fig. 2) and eleven of reptiles [Boa constrictor, Dipsas albifrons, D. alternans, D. indica (Fig. 3A), Echinantera cephalostriata (Fig. 3B), Erythrolamprus aesculapii, Liotyphlops wilderi, Mastigodryas bifossatus, Ophiodes cf. striatus, Philodryas olfersii and Xenodon merremi] (see Appendix 1 for voucher specimens). Additionally, one species (the frog Cycloramphus fuliginosus; see below) is herein removed from the previous list. We also confirm the occurrence of the snake Corallus hortulanus in the island on the basis of vouchered specimens in collections (see Appendix 1) and one individual photographed (but not collected) in the Vila do Aventureiro village during our fieldwork (Fig. 4).

The amphibian richness presently registered for Ilha Grande corresponds to $3.1 \%$ of the amphibian species known to occur in Brazil (Segalla et al., 2016), to 6.3\% of the species known from the Atlantic Forest domain (Haddad et al., 2013) and to ca. 18\% of the species reported for the state of Rio de Janeiro (Rocha et al., 2004a; Vrcibradic et al., 2011). The richness of non-marine reptiles occurring in Ilha Grande corresponds to ca. $5 \%$ of that of Brazil (Costa \& Bérnils, 2015), to $19 \%$ of that of the Atlantic Forest (Martins \& Molina, 2008) and to ca. 30\% of that of the state of Rio de Janeiro (Rocha et al. 2004a; Vrcibradic et al., 2011). These numbers indicate that Ilha Grande is an important reservoir of the biodiversity of Atlantic rainforest amphibians and reptiles and point out the importance of the conservation of the different environments along the island landscape.

Rocha etal. (2009) remarked that the ParkManagement Directive Plan (UFRRJ/IEF/PRONATURA, 1992) of the PEIG cited three amphibian species not present in their list: Leptodactylus ocellatus (Linnaeus, 1758) (currently L. latrans), Hyla albofrenata Lutz, 1924 (currently Aplastodiscus albofrenatus) and Ololygon perpusilla (Lutz \& Lutz, 1939). The occurrence of L. latrans in Ilha Grande is here confirmed through both primary and secondary data. The record of $A$. albofrenatus was almost certainly based on A. eugenioi, a taxon that had not yet been described at the time of the report and was then considered as part of A. albofrenatus (see Carvalho-e-Silva \& Carvalho-e-Silva, 2005). Finally, the record of Ololygon perpusilla is probably referable to an apparently undescribed species of the O. perpusilla group (referred to as Scinax gr. perpusillus by Bittencourt-Silva \& Silva, 2013).

Two of the species reported as new records in our study have been recorded only through photographs, as physical specimens could not be secured. This was the case of the frog Leptodactylus flavopictus (whose record was based on a specimen that evaded capture) and of 

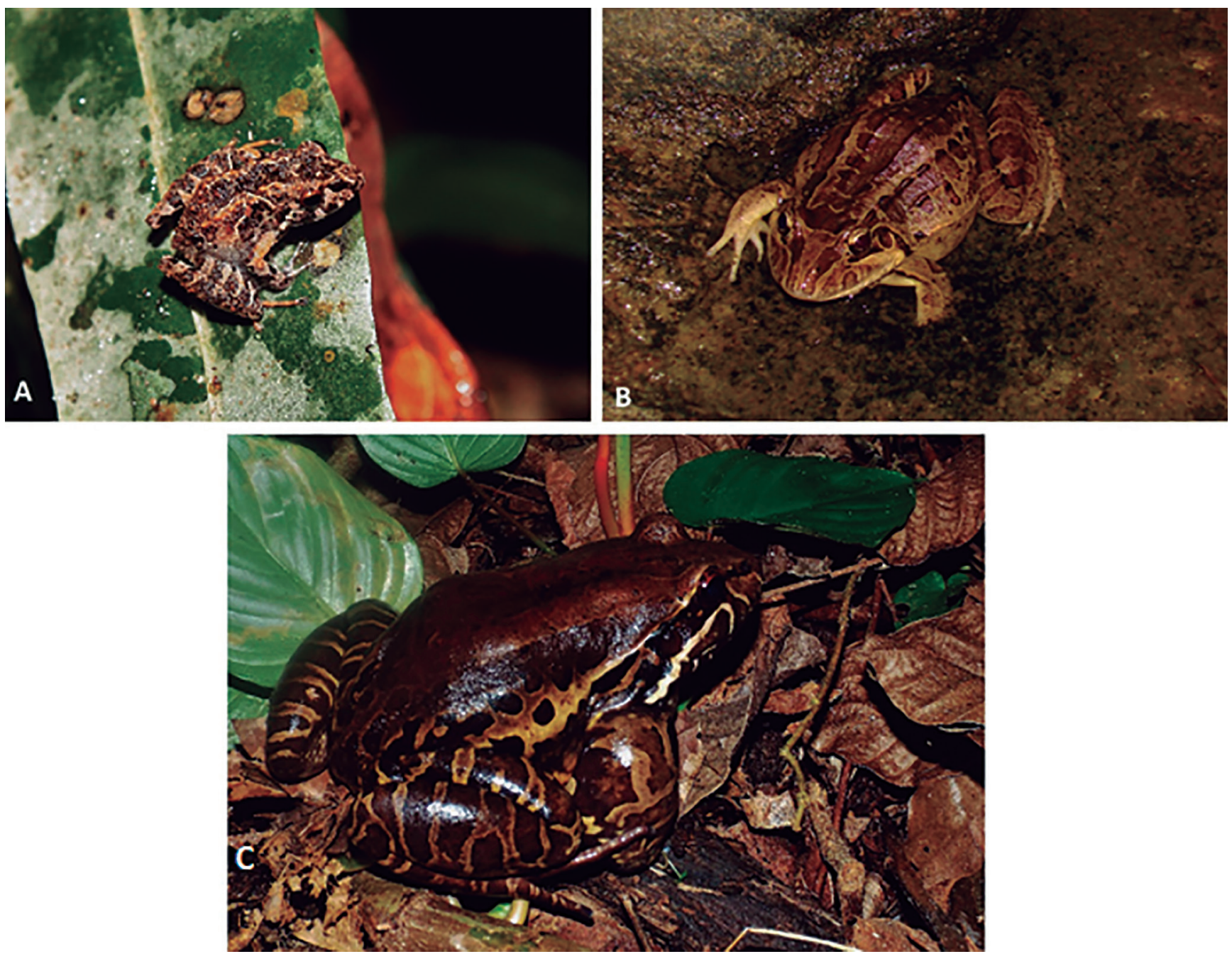

Figure 2. New records of amphibians for llha Grande. (A) Ischnocnema bolbodactyla; (B) Leptodactylus latrans; (C) Leptodactylus flavopictus (Photos by F.B.S. Telles).
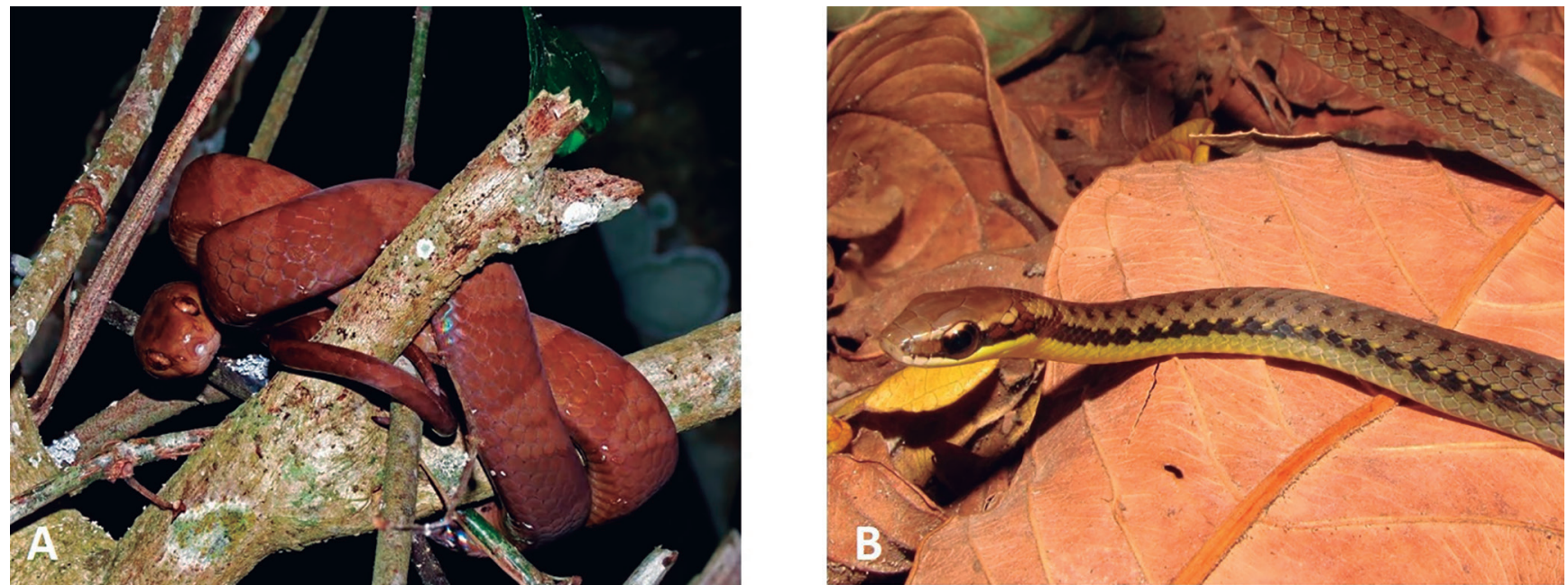

Figure 3. New records of snakes for llha Grande. (A) Dipsas indica (Photo by D. Cunha-Passos); (B) Echinantera cephalostriata (Photo by P. Fatorelli).

the snake Dipsas indica. The latter species was recorded by a colleague who photographed one specimen but could not collect it since he did not have a collecting permit. A previous record based only on a photograph was that of the toad Rhinella icterica reported by BittencourtSilva \& Silva (2013). Since all those species are relatively large-bodied and can be easily told apart from other congeners occurring in the Atlantic Forest of southeastern Brazil, it was possible to identify them accurately from the images.

The only exotic species registered in the island's herpetofauna was Hemidactylus mabouia, an invasive species in Brazil that is commonly associated to anthropic and peri-anthropic environments and also occurs in 
Table 1. Species of amphibians and reptiles recorded at llha Grande (Angra dos Reis, Rio de Janeiro, Brazil). New records for llha Grande are marked with an asterisk $\left({ }^{*}\right)$. Taxa whose species epithets have changed since they appeared in the lists of Rocha et al. (2009) and in Bittencourt-Silva \& Silva (2013) are marked with letters. $\mathrm{EN}=$ Endemism; $\mathrm{AF}=$ Atlantic Forest; $I \mathrm{G}=\mathrm{Ilha}$ Grande. Sources for new records (and for previously cited but unvouchered records) are given as: $p=$ primary data; $s=$ secondary data (from specimens in collections); ph = photographic record; Literature sources for previous records are: $1=$ Rocha et al., 1997; $2=$ Rocha et al., 1998; 3 = Rocha et al., 1999; 4 = van Sluys \& Rocha, 1999; 5 = Boquimpani-Freitas et al., 2001; 6 = van Sluys et al., 2001; 7 = Rocha et al., 2001; 8 = Hatano et al., 2002; 9 = Boquimpani-Freitas et al., 2002; $10=$ Rocha et al., 2002; $11=$ Rocha \& Vrcibradic, 2003; $12=$ van Sluys et al., 2004; $13=$ Rico et al., $2004 ; 14=$ Rocha et al., 2004b; 15 = Marra et al., 2004; 16 = Siqueira et al., 2006a; 17 = Siqueira et al., 2006b; 18 = Ariani et al., 2006; $19=$ Bursey et al., 2006; 20 = Vrcibradic et al., 2006; 21 = van Sluys et al., 2006; 22 = Rocha \& van Sluys, 2006; 23 = Almeida-Gomes et al., 2007a; 24 = Almeida-Gomes et al., 2007b; 25 = Almeida-Gomes et al., 2007c; 26 = Almeida-Gomes et al., 2007d; 27 = Borges-Junior et al., 2007; 28 = Hatano et al., 2007; 29 = van Sluys et al., 2007; 30 = Boquimpani-Freitas et al., 2007; 31 = Rocha et al., 2009; 32 = Fatorelli et al., 2010; 33 = Laia et al., 2010; $34=$ Rocha \& Bergallo, 2011; $35=$ Winck et al., 2011; $36=$ van Sluys et al., $2012 ; 37=$ Goyannes-Araújo et al., 2015; 38 = Jackson, 1978; 39 = Heyer, 1983; 40 = Carvalho-e-Silva \& Carvalho-e-Silva, 2005; 41 = Canedo \& Pombal Jr., 2007; 42 = Prado \& Pombal Jr., 2008; 43 = Bittencourt-Silva \& Silva, 2013; $44=$ Telles et al., 2015; $45=$ INEA, 2013. Sites of occurrence (based on both primary and secondary data): $C A X=$ Caxadaço trail; $C D M=$ Costão do Demo, RBEPS; EAD = Abraão-Dois Rios road; FPS = Praia do Sul forest; JAR = Jararaca trail, Dois Rios; LPM = Lopes Mendes; PAP = Pico do Papagaio; PRN = Parnaioca trail; RPS = Praia do Sul restinga; VAB = Vila do Abraão; VAV = Vila do Aventureiro; VDR=Vila Dois Rios.

\begin{tabular}{|c|c|c|c|}
\hline Taxa & EN & Source & Site of occurrence \\
\hline \multicolumn{4}{|l|}{ AMPHIBIA } \\
\hline \multicolumn{4}{|l|}{ ANURA } \\
\hline \multicolumn{4}{|l|}{ Brachycephalidae } \\
\hline Brachycephalus didactylus (Izecksohn, 1971) & $\mathrm{AF}$ & $7,29,31,37,43$ & JAR, PAP \\
\hline Ischnocnema bolbodactyla (A. Lutz, 1925)* & AF & $\mathrm{p}$ & FPS, RPS, VAV \\
\hline Ischnocnema guentheri (Steindachner, 1864) & AF & $7,18,29,31,37,43$ & CAX, FPS, JAR, PAP, VAV \\
\hline Ischnocnema octavioi (Bokermann, 1965) & $\mathrm{AF}$ & 31,43 & CAX, VAV \\
\hline Ischnocnema parva (Girard, 1853) & $\mathrm{AF}$ & $7,15,29,30,31,36,37,43$ & FPS, JAR, LPM, PAP, RPS, VAV \\
\hline \multicolumn{4}{|l|}{ Bufonidae } \\
\hline Dendrophryniscus brevipollicatus Jiménez de la Espada, 1870 & AF & $7,29,31,37,43$ & CAX, EAD, FPS, JAR, LPM, PAP, RPS, VAV \\
\hline Rhinella icterica (Spix, 1824) & AF & 43 & VAB \\
\hline Rhinella ornata (Spix, 1824) & $\mathrm{AF}$ & $31,37,43$ & CAX, CDM, EAD, FPS, JAR, LPM, PAP, RPS, VAB, VAV, VDR \\
\hline \multicolumn{4}{|l|}{ Centrolenidae } \\
\hline Vitreorana eurygnatha (Lutz, 1925) & $\mathrm{AF}$ & 43 & $?$ \\
\hline \multicolumn{4}{|l|}{ Craugastoridae } \\
\hline Haddadus binotatus (Spix, 1824) & $\mathrm{AF}$ & $7,31,37,43$ & CAX, EAD, FPS, JAR, LPM, PAP, RPS, VAV, VDR \\
\hline \multicolumn{4}{|l|}{ Cycloramphidae } \\
\hline Cycloramphus boraceiensis Heyer, 1983 & $\mathrm{AF}$ & $31,39,43$ & FPS, VAB \\
\hline Thoropa miliaris (Spix, 1824) & AF & $10,16,17,31,37,43$ & CAX, CDM, FPS, JAR, LPM, PAP, PRN, RPS, VAV, VDR \\
\hline Zachaenus parvulus (Girard, 1853) & $\mathrm{AF}$ & $2,6,7,29,31,37,43$ & JAR, PAP, PRN \\
\hline \multicolumn{4}{|l|}{ Hemiphractidae } \\
\hline Fritziana sp. & AF & 37,43 & PAP \\
\hline \multicolumn{4}{|l|}{ Hylidae } \\
\hline Aplastodiscus eugenioi (Carvalho-e-Silva \& Carvalho-e-Silva, 2005) & AF & $30,31,36,37,40,43$ & CAX, EAD, FPS, PAP, PRN, VAV \\
\hline Boana albomarginata (Spix, 1824) & $\mathrm{AF}$ & 31,43 & VAB, VDR \\
\hline Boana faber (Wied-Neuwied, 1821) & AF & 31,43 & VDR \\
\hline Bokermannohyla circumdata (Cope, 1871) & AF & $3,31,43$ & PAP,VDR \\
\hline Itapotihyla langsdorffii (Duméril \& Bibron, 1841) & AF & 31,43 & CAX, FPS, PRN, RPS, VAB, VAV, VDR \\
\hline Ololygon trapicheiroi (A. Lutz \& B. Lutz, 1954) & AF & $13,18,21,27,30,31,36,43$ & CAX, EAD, FPS, PAP, PRN \\
\hline Ololygon sp. (gr. perpusillus) & IG & 31,43 & CDM, RPS, VAV \\
\hline Scinax fuscovarius (Lutz, 1925) & & 43 & $?$ \\
\hline Scinax hayii (Barbour, 1909) & $\mathrm{AF}$ & $30,31,36,43$ & EAD, JAR, PRN, VDR \\
\hline \multicolumn{4}{|l|}{ Hylodidae } \\
\hline Crossodactylus gaudichaudii Duméril \& Bibron, 1841 & $\mathrm{AF}$ & $24,25,26,31,37,43$ & CAX, EAD, FPS, PAP \\
\hline Hylodes asper (Müller, 1924) & $\mathrm{AF}$ & 37,43 & PAP \\
\hline Hylodes fredi Canedo \& Pombal, 2007ª & IG & $1,8,19,25,28,31,33,37,41,43$ & CAX, FPS, JAR, PAP, PRN \\
\hline \multicolumn{4}{|l|}{ Leptodactylidae } \\
\hline Adenomera marmorata (Steindachner, 1867) & AF & $7,23,29,30,31,36,37,43$ & CAX, EAD, FPS, JAR, RPS, PAP, PRN, VAV \\
\hline Leptodactylus flavopictus Lutz, 1926* & $\mathrm{AF}$ & $\mathrm{p}(\mathrm{ph})$ & FPS \\
\hline Leptodactylus latrans (Steffen, 1815)* & & $\mathrm{p}, \mathrm{s}$ & CDM, LPM, VAB \\
\hline Physalaemus signifer (Girard, 1853) & $\mathrm{AF}$ & $18,30,31,36,37,43$ & CAX, EAD, FPS, LPM, PAP, PRN, RPS, VAV \\
\hline \multicolumn{4}{|l|}{ Microhylidae } \\
\hline Chiasmocleis lacrimae Peloso, Sturaro, Forlani, Gaucher, Motta \& Wheeler, 2014 & AF & $7,18,29,31,37,43$ & EAD, FPS, JAR, PAP, PRN, RPS, VAV, VDR \\
\hline Myersiella microps (Duméril \& Bibron, 1841) & AF & $31,37,43$ & JAR, PAP, VAV \\
\hline \multicolumn{4}{|l|}{ Odontophrynidae } \\
\hline Proceratophrys tupinamba Prado \& Pombal, 2008c & IG & $3,5,7,9,31,32,37,42,43$ & JAR, PAP, VDR \\
\hline \multicolumn{4}{|l|}{ Phyllomedusidae } \\
\hline Phasmahyla guttata (Lutz, 1924) & AF & 37,43 & PAP \\
\hline
\end{tabular}




\begin{tabular}{|c|c|c|c|}
\hline Taxa & EN & Source & Site of occurrence \\
\hline \multicolumn{4}{|l|}{ REPTILIA } \\
\hline \multicolumn{4}{|l|}{ CROCODYLIA } \\
\hline \multicolumn{4}{|l|}{ Alligatoridae } \\
\hline Caiman latirostris (Daudin, 1802) & & 31,45 & LPM \\
\hline \multicolumn{4}{|l|}{ SQUAMATA - LACERTILIA } \\
\hline \multicolumn{4}{|l|}{ Anguidae } \\
\hline Diploglossus fasciatus (Gray, 1831) & & 22,31 & VAV, VDR \\
\hline Ophiodes cf. striatus (Spix, 1825)* & & s & $?$ \\
\hline \multicolumn{4}{|l|}{ Dactyloidae } \\
\hline Anolis punctatus Daudin, 1802 & & 31,35 & CAX \\
\hline \multicolumn{4}{|l|}{ Gekkonidae } \\
\hline Hemidacty/us mabouia (Moureau de Jonnès, 1818) & & $22,31,34,44$ & CDM, RPS, VAV, VDR \\
\hline \multicolumn{4}{|l|}{ Gymnophthalmidae } \\
\hline Placosoma glabellum (Peters, 1870) & $\mathrm{AF}$ & 22,31 & VDR \\
\hline Ecpleopus gaudichaudii Duméril \& Bibron, 1839 & AF & 22,31 & VDR \\
\hline \multicolumn{4}{|l|}{ Leiosauridae } \\
\hline Enyalius brasiliensis (Lesson, 1828) & $\mathrm{AF}$ & $12,22,31,38$ & FPS, VDR \\
\hline \multicolumn{4}{|l|}{ Mabuyidae } \\
\hline Brasiliscincus agilis (Raddi, 1823) & AF & $11,14,20,22,31$ & RPS, VDR \\
\hline \multicolumn{4}{|l|}{ Phyllodactylidae } \\
\hline Gymnodactylus darwinii (Gray, 1845) & AF & $18,22,31$ & RPS, VAB, VDR \\
\hline \multicolumn{4}{|l|}{ Teiidae } \\
\hline Salvator merianae Duméril \& Bibron, 1839 & & $4,22,31$ & FPS, RPS, VDR, VAV \\
\hline \multicolumn{4}{|l|}{ Tropiduridae } \\
\hline Tropidurus torquatus (Wied, 1820) & & 31,35 & LPM \\
\hline \multicolumn{4}{|l|}{ SQUAMATA - AMPHISBAENIA } \\
\hline \multicolumn{4}{|l|}{ Amphisbaenidae } \\
\hline Leposternon microcephalum (Wagler in Spix, 1824) & & 22,31 & FPS, VDR \\
\hline \multicolumn{4}{|l|}{ SQUAMATA - SERPENTES } \\
\hline Anomalepididae & & & \\
\hline Liotyphlops wilderi (Garman, 1883)* & AF & $\mathrm{s}$ & ? \\
\hline Boidae & & & \\
\hline Boa constrictor (Linnaeus, 1758)* & & s & $?$ \\
\hline Corallus hortulanus (Linnaeus, 1758) & & $\mathrm{p}(\mathrm{ph}), \mathrm{s}, 31$ & VAB, VAV \\
\hline Colubridae & & & \\
\hline Chironius bicarinatus (Wied, 1820) & & 22,31 & $\mathrm{VAB}, \mathrm{VDR}$ \\
\hline Chironius exoletus (Linnaeus, 1758) & & 22,31 & VDR \\
\hline Chironius foveatus Bailey, 1955 & & $3,22,31$ & VDR \\
\hline Spilotes pullatus (Linnaeus 1758) & & 22,31 & FPS, RPS, VAB, VAV, VDR \\
\hline Dipsadidae & & & \\
\hline Clelia plumbea (Wied, 1820) & & 22,31 & VDR \\
\hline Dipsas albifrons (Sauvage, 1884)* & & s & $\mathrm{VAB}$ \\
\hline Dipsas alternans (Fischer, 1885$)^{*}$ & $\mathrm{AF}$ & s & $?$ \\
\hline Dipsas indica (Fischer, 1885)* & & $\mathrm{p}(\mathrm{ph})$ & VDR \\
\hline Echinantera cephalostriata Di-Bernardo, 1996* & AF & $\mathrm{p}$ & CAX \\
\hline Erythrolamprus aesculapii (Linnaeus, 1766)* & & s & $?$ \\
\hline Erythrolamprus miliaris (Linnaeus, 1758) & & 22,31 & $\mathrm{VAB}, \mathrm{VDR}$ \\
\hline Erythrolamprus poecilogyrus (Wied, 1825) & & 22,31 & $\mathrm{VAB}, \mathrm{VDR}$ \\
\hline Imantodes cenchoa (Linnaeus, 1758) & & 22,31 & VDR \\
\hline Mastigodryas bifossatus (Raddi, 1820)* & & s & $?$ \\
\hline Oxyrhopus clathratus Duméril, Bibron \& Duméril, 1854 & AF & 22,31 & VAV, VDR \\
\hline Philodryas olfersii (Liechtenstein, 1823)* & & s & $\mathrm{VAB}$ \\
\hline Sibynomorphus neuwiedi (Ihering, 1911) & & 22,31 & FPS, VAB, VAV, VDR \\
\hline Siphlophis pulcher (Raddi, 1820) & $\mathrm{AF}$ & 22,31 & VAV, VDR \\
\hline Thamnodynastes cf. nattereri (Mikan, 1828) ${ }^{d}$ & & $18,22,31$ & CAX, FPS, RPS, VAB, VDR \\
\hline Xenodon merremii (Wagler in Spix, 1824)* & & s & $?$ \\
\hline Xenodon neuwiedii Günther, 1863 & & 22,31 & VDR \\
\hline Elapidae & & & \\
\hline Micrurus corallinus (Merrem, 1820) & $\mathrm{AF}$ & 22,31 & FPS, JAR, PRN, VAB, VDR \\
\hline Viperidae & & & \\
\hline Bothrops jararaca (Wied, 1824) & AF & 22,31 & FPS, JAR, VAB, VDR \\
\hline Bothrops jararacussu Lacerda, 1884 & & 22,31 & VDR \\
\hline
\end{tabular}

$a=$ Referred to Hylodes phyllodes Heyer \& Cocroft, 1986 prior to 2007;

$b=$ Previously cited as Chiasmocleis carvalhoi Cruz, Caramaschi \&. Izecksohn, 1997 or as Chiasmocleis sp.;

$c=$ Referred to Proceratophrys appendiculata (Günther, 1873) prior to 2008;

$d=$ Previously cited as Thamnodynastes strigilis (Thunberg, 1787). 


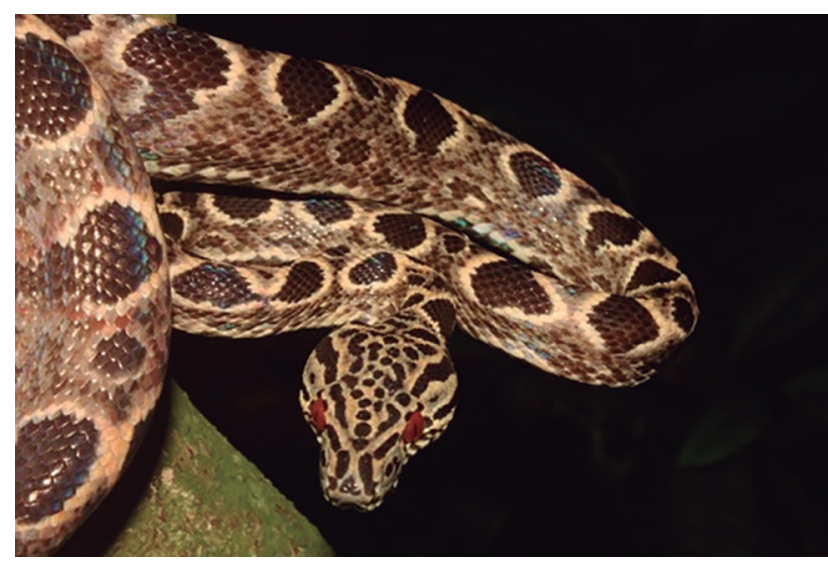

Figure 4. Specimen of Corallus hortulanus (not collected) found in Vila do Aventureiro village, llha Grande (Photo by F.B.S. Telles).

open natural areas (Rocha et al., 2011). In Ilha Grande, it was considered as an exotic species but not as invasive in natural environments (Rocha \& Bergallo, 2011). Recent systematic surveys on different environments within the island have failed to record the occurrence of this gecko outside anthropic and peri-antropic habitats (Rocha \& Bergallo, 2011; Winck, 2012). However, more recent surveys carried out by our research team have recorded 17 individuals (and two eggs) of $H$. mabouia in natural environments of Praia do Sul, in the RBEPS, thus evidencing that this species has become an invasive exotic in that area (Telles et al., 2015). Considering the two previous surveys in the island that did not find this lizard in natural environments, we suggest that the invasion of the restinga habitat in Praia do Sul by this gecko may be quite recent. According to our data, Rhinella ornata, Thoropa miliaris and Haddadus binotatus were the most widely distributed anurans in Ilha Grande, occurring, respectively, in eleven, ten and nine different localities throughout the island (Table 1). Bittencourt-Silva \& Silva (2013), sampling seven islands along the coast of Rio de Janeiro State, found that the rupicolous frog T. miliaris was the only amphibian inhabiting all the islands analyzed. Thus, this species appears to have a great potential for dispersal and colonization. Among reptiles, the species registered in the most localities were Spilotes pullatus and Thamnodynastes cf. nattereri, both being recorded in five different sites (Table 1). Of the 33 reptiles for which specific locality data were available, 15 (45.4\%) had their occurrence reported from a single locality (Table 1), which probably reflects mostly a deficit of survey efforts rather than geographic restriction of taxa within the island.

The oldest representative of the Ilha Grande herpetofauna found by us in the scientific collections surveyed was an individual of the cycloramphid frog Thoropa miliaris collected in Praia do Sul in 1941, which is currently deposited in the amphibian collection of Museu Nacional (MNRJ 58941; collector unknown). There are other specimens of various amphibian and reptile taxa in the collections of Museu Nacional and Universidade Federal do Rio de Janeiro that have been collected in the 1940s by the German ornithologist Helmut Sick, during his stay at the prison of Vila dos Dois Rios village between 1942 and
1945 (Vuilleumier, 1998). Some of those specimens constitute the sole representatives of their species recorded so far for Ilha Grande, like the glass frog Vitreorana eurygnatha, the lizard Ophiodes cf. striatus, and the snakes Boa constrictor, Dipsas alternans, Erythrolamprus aesculapii, Liotyphlops wilderi and Mastigodryas bifossatus. The fact that no further specimens of those taxa have been collected in the island in over seven decades may have a number of different causes, such as: low density of those taxa in Ilha Grande, low detectability (e.g., in the case of the fossorial snake Liotyphlops), occurrence of those taxa in undersampled regions of the island, local extinction and/or possible mislabeling of specimens (see below).

The knowledge about the Ilha Grande herpetofauna has been amassed over the last seven decades, starting with the first deposits in scientific collections of specimens collected in the 1940s. There has been a consistent increase in the last two decades since the creation of the Centro de Estudos Ambientais e Desenvolvimento Sustentável of the Universidade do Estado do Rio de Janeiro (CEADS/UERJ) in 1996, which is located in Vila Dois Rios village. The creation of CEADS allowed the development of new research projects with various groups of fauna and flora of the island (Callado et al., 2009; Rocha et al., 2009). However, the logistical facility provided by the CEADS potentially promoted a bias in the research on herpetofauna (and also on other groups of animals and plants), concentrating most of the studies in the forests around Vila Dois Rios village, on the seaward side of the island. Indeed, Vila Dois Rios was the locality with the highest number of herpetofaunal species recorded for Ilha Grande (see Fig. 1).

\section{Taxonomic remarks}

\section{Amphibia}

Chiasmocleis - Specimens of this genus recorded at llha Grande have been usually referred as Chiasmocleis sp. (Rocha et al., 2000, 2001, 2004a, 2009; Ariani et al., 2006; van Sluys et al., 2007; Goyannes-Araújo et al., 2015). Rocha et al. (2004a) and Goyannes-Araújo et al. (2015) commented that the Chiasmocleis from Ilha Grande was an undescribed species. Bittencourt-Silva \& Silva (2013), on the other hand, referred to the species occurring in Ilha Grande as C. carvalhoi (now C. lacrimae; see Peloso et al., 2014). Tonini et al. (2014), in a molecular phylogenetic analysis of the C. lacrimae and C. capixaba complexes, used DNA sequences of three specimens of Chiasmocleis from "Angra dos Reis, Rio de Janeiro" housed at the herpetological collection of the Universidade Federal Rural do Rio de Janeiro. Those specimens (RU 7003-05; referred as RN 7003-05 in Tonini et al., 2014) are actually from Ilha Grande, and are determined as Chiasmocleis gr. carvalhoi in that collection's catalog (curiously, they are not listed in the Appendix I of Bittencourt-Silva \& Silva, 2013). In Tonini et al.'s (2014) phylogeny their DNA sequences grouped with other samples from the states of Rio de Janeiro and São Paulo in a clade that those authors 
considered to be assignable to C. lacrimae (sensu stric$t u)$. Thus, the species of Chiasmocleis that occurs in Ilha Grande can be referred to C. lacrimae (assuming that only one species of that genus occurs there).

Cycloramphus - Both Rocha et al. (2009) and BittencourtSilva \& Silva (2013) listed two species of the genus Cycloramphus for Ilha Grande: Cycloramphus boraceiensis and C. fuliginosus. In the Appendix of their article, Bittencourt-Silva \& Silva (2013) cite a voucher number for C. boraceiensis but none for C. fuliginosus, instead referring to the citation by Rocha et al. (2009) to justify its presence on the list (indeed, C. fuliginosus is the only species in their list for which no voucher specimens are mentioned). The specimen cited in that work (MNRJ 48118) was checked by the authors at the collection of the Museu Nacional. The name $C$. boraceiensis was written in the label inside the vial in which it is kept, but in the museum catalog this same specimen is referred as C. fuliginosus. Thus, it seems that the records of two species of Cycloramphus for Ilha Grande are based on a single specimen. Cycloramphus boraceiensis is the only species of the genus previously reported for Ilha Grande (Heyer, 1983). Heyer's (1983) record of this species for the island is based on an individual in the Museu Nacional (MNRJ 2241, also examined by us) that had been collected by H. Sick in 1944. During fieldwork at the RBEPS one of us (FBST) collected three individuals of Cycloramphus (subsequently deposited at the Museu Nacional under the numbers MNRJ 89138-40). Using Heyer's (1983) dichotomic key to the species of Cycloramphus known at the time and making direct comparisons with MNRJ 2241 we were able to confirm the identification of MNRJ 48118 as C. boraceiensis and to determine that our three new specimens were $C$. boraceiensis as well. Thus, it seems that $C$. boraceiensis is currently the only species of the genus known to occur at Ilha Grande and, therefore, C. fuliginosus should be excluded from the island's list of amphibians.

Ischnocnema - Ischnocnema octavioi was first reported for Ilha Grande by Rocha et al. (2000, 2001), but that record was later found to be based on two misidentified specimens of I guentheri (Vrcibradic et al., 2008). Bittencourt-Silva \& Silva (2013) reported the occurrence of I octavioi in Ilha Grande based on a third specimen, MNRJ 60158 (the two previously mentioned specimens, MNRJ 47972-73, were correctly listed by them under I guentheri). The specimen MNRJ 60158 was collected by a colleague and is, in fact, I octavioi, which confirms the occurrence of this species in the island.

Physalaemus - There were two specimens at the Museu Nacional determined as Physalamus angrensis (MNRJ 56473-74), having been collected at Praia do Sul. Those specimens were re-examined and re-identified as young individuals of Physalaemus signifer (M. WoitoviczCardoso, pers. comm.), a relatively common species in Ilha Grande, where it occurs in various localities, including the RBEPS (Table 1).

\section{Reptilia}

Ophiodes - The lizard genus Ophiodes is currently a problematic taxon, requiring a comprehensive review. One individual at the collection of Museu Nacional is labeled Ophiodes fragilis (Raddi, 1820). The name O. fragilis has been widely used for specimens from southeastern Brazil and portions of Argentina and Paraguay (Pizzatto, 2005; Avila et al., 2013; Cacciali \& Scott, 2015). Nevertheless, a proper redescription and revalidation of $O$. fragilis has not yet been published (Costa \& Bérnils, 2015). Thus, we follow Montechiaro et al. (2011) and take a conservative stance by referring to the specimen from Ilha Grande as Ophiodes cf. striatus.

Thamnodynastes - Snakes from the genus Thamnodynastes from Ilha Grande present another taxonomic problem. They have been referred to as Thamnodynastes strigilis by Ariani et al. (2006) and Rocha et al. (2009), and as Thamnodynastes cf. strigilis by Rocha \& van Sluys (2006), but T. strigilis is currently considered a synonym of $T$. pallidus, a species that does not occur in southeastern Brazil (Bailey et al., 2005). The name T. nattereri (or T. cf. nattereri) have also been recently attributed to the Atlantic Forest Thamnodynastes commonly referred to "strigilis" or "cf. strigilis" in the literature (Dorigo et al., 2014; Franco et al., 2017). Indeed, the specimens from Ilha Grande deposited in the institutional collections we surveyed are all labeled as either T. cf. nattereri, Thamnodynastes sp., or (in one case) T. pallidus nattereri. For the present list we conventionally follow the most recent authors and attribute the name Thamnodynastes cf. nattereri for the specimens from Ilha Grande, though we are aware that this is a provisional designation, given the current nomenclatural problems involving the epithet "nattereri" (Franco \& Ferreira, 2002; Bellini et al., 2014; Dorigo et al., 2014; Franco et al., 2017).

\section{Probable erroneous records}

Some of the records from Ilha Grande based on secondary data are problematic, as the species involved are not known to occur in the state of Rio de Janeiro or even in the Atlantic Forest biome. We believe those records contain erroneous information and, therefore, they were not included in the list. This is the case of two lizard specimens at the reptile collection of the Museu Nacional. One of them (MNRJ 19748), referred to Anolis auratus in the museum's catalog, has been collected in 1986 by the personnel of the "Projeto Ilha Grande". Unfortunately, that specimen could not be located at the museum's collection, so we could not verify its identity. Nevertheless, since $A$. auratus is a species confined to the Amazon region (Ávila-Pires, 1995), we assume the specimen must have been misidentified. The other problematic specimen is MNRJ 15512, identified as Tropidurus spinulosus and collected by H. Sick in 1944, according to the catalog. That specimen was examined by us and is indeed a member of the T. spinulosus group. However, species of the T. spinulosus group do not occur in the Atlantic for- 
ests of southeastern Brazil (Carvalho, 2013, 2016), which indicates that the locality of collection given for MNRJ 15512 is probably erroneous.

\section{Conservation issues}

Among the herpetofauna species recorded for llha Grande, amphibians had a high rate of endemism for the Atlantic Forest Biome ( $94 \%$ of the species were endemic). This high degree of endemism is characteristic of the amphibian fauna of this biome, in which $88 \%$ of the species are endemic according to Haddad et al. (2013). Regarding reptiles, 12 species were endemic to the Atlantic Forest (five lizards and seven snakes), representing about a third of the species recorded for the island.

In spite of the high rate of endemism among amphibians, most species are categorized as being of "Least Concern" in terms of their conservation status in the global scope (according to criteria of the IUCN - International Union for the Conservation of Nature). The only species from Ilha Grande included in an actual threat category by the IUCN is Chiasmocleis lacrimae, which is currently considered as "Endangered", mainly due to habitat degradation within its area of occurrence and the presumed trend for decline of its populations [see Stuart et al., 2008 (as C. carvalhoi)]. The only other species of the Ilha Grande herpetofauna not categorized as "Least Concern" is the hylodid Hylodes fredi, a species endemic to the island, which is considered as "Data Deficient" (DD) due to the lack of information on "its extent of occurrence, area of occupancy, status and ecological requirements" (Angulo, 2008). Nevertheless, we caution that, in terms of conservation, particular attention should be paid to hylodids, as well as to any other species whose life is restricted to forest streams, as we believe those species are particularly vulnerable to environmental disturbances. Hylodids have had their real threat status underestimated since the current form of extinction risk assessment by IUCN for species restricted to streams seems to overestimate the actual area of occupation for these species which is likely much more spatially limited (Almeida-Gomes et al., 2014). The other frog species endemic to llha Grande, the odontophrynid Proceratophrys tupinamba, is not yet categorized by IUCN, probably because its description is relatively recent (Prado \& Pombal Jr., 2008). However, we think these two species that occur only in Ilha Grande carry conservation concern because they have a very restricted distribution and depend on the effective conservation of that particular insular environment.

Among the reptiles, only two species of lizards (Salvator merianae and Tropidurus torquatus), three of snakes (Siphlophis pulcher, Xenodon neuwiedii and Bothrops jararacussu) and one crocodilian (Caiman latirostris) are categorized by the IUCN, but all in the category of "Least Concern". The broad-snouted caiman (C. latirostris), although believed to be an introduced species in Ilha Grande (INEA, 2013), is the only taxon on the island that is included in the Rio de Janeiro state list of threatened fauna (classified as "Endangered"; Bergallo et al. 2000). However, at the national level, none of the species of the llha Grande reptile fauna is categorized as having a conservation risk (Haddad, 2008; Martins \& Molina, 2008).

In conclusion, our data indicated that llha Grande houses a considerable portion of Atlantic Forest amphibian and reptile diversity together with a predominance of species endemic to this biome, plus a few species endemic to that island. This indicates that Ilha Grande is an important reservoir of both biodiversity and endemism of amphibians and reptiles of the Atlantic Forest of southeastern Brazil, which points out the importance of the conservation of this island and its different habitats along the insular landscape. We also point out that several portions of Ilha Grande remain unexplored, particularly in respect to the herpetofauna (as is evident from Fig. 1), and that still more species of amphibians and reptiles are likely to be added to the present list if field surveys in that island are intensified.

\section{ACKNOWLEDGEMENTS}

This study is portion of the results of the "Programa de Pesquisas em Biodiversidade da Mata Atlântica (PPBio Mata Atlântica Program)" of Ministério do Meio Ambiente do Brasil (MMA) and was supported by Conselho Nacional de Desenvolvimento Científico e Tecnológico (CNPq) (process No. 457458/2102-7). The authors benefitted from grants provided to CFDR (302974/2015-6 and 472287/2012-5) from Conselho Nacional do Desenvolvimento Científico e Tecnológico (CNPq), from Biota FAPERJ Program (E-26/10.1639/2014) and through "Cientistas do Nosso Estado" Program from FAPERJ to CFDR (process No. E-26/102.765.2012 and E-26/202.920.2015). FBST and PNC received respectively $\mathrm{PhD}$ and Post-Doctoral fellowships from Conselho Nacional do Desenvolvimento Científico e Tecnológico (CNPq) and from FAPERJ (processes E-26/201.760/2015, E-26/201.829/2015). The ICMBio provided the permits for the collection of zoological specimens (No. 46327-4 and 17474-1) and the Instituto Estadual do Ambiente - INEA granted an authorization for the research in Ilha Grande (IEF/RJ 003/2008-2015).

\section{REFERENCES}

Alho, C.J.R.; Schneider, M. \& Vasconcellos, L.A. 2002. Degree of threat to the biological diversity in the llha Grande State Park (RJ) and guidelines for conservation. Brazilian Journal of Biology, 62: 487-494.

Almeida-Gomes, M.; Lorini, M.L.; Rocha, C.F.D. \& Vieira, M.V. 2014. Underestimation of extinction threat to stream-dwelling amphibians due to lack of consideration of narrow area of occupancy. Conservation Biology, 28: 616-619.

Almeida-Gomes, M.; van Sluys, M. \& Rocha, C.F.D. 2007a. Ecological observations on the leaf-litter frog Adenomera marmorata in an Atlantic rainforest area of southeastern Brazil. Herpetological Journal, 17: 81-85.

Almeida-Gomes, M.; Hatano, F.H.; van Sluys, M. \& Rocha, C.F.D. 2007b. Diet and microhabitat use by two Hylodinae species (Anura, Cycloramphidae) 
living in sympatry and syntopy in a Brazilian Atlantic Rainforest area. Iheringia, Série Zoologia, 97: 27-30.

Almeida-Gomes, M.; van Sluys, M. \& Rocha, C.F.D. 2007c. Calling activity of Crossodactylus gaudichaudii (Anura: Hylodidae) in an Atlantic Rainforest area at Ilha Grande, Rio de Janeiro, Brasil. Belgian Journal of Zoology, 137: 203-207.

Almeida-Gomes, M.; van Sluys, M. \& Rocha, C.F.D. 2007d. Crossodactylus gaudichaudii (Gaudichaud's Frog) Behavior. Herpetological Review, 38: 181-182.

Alves, M.A.S. \& Vecchi, M.B. 2009. Birds, llha Grande, state of Rio de Janeiro, Southeastern Brazil. Check List, 5: 300-313.

Angulo, A. 2008. Hylodes fredi. In: The IUCN Red List of Threatened Species: e.T136039A4238364. Access in: 20/06/2017. D0l

Ariani, C.V.; Rocha, C.F.D. \& van Sluys, M. 2006. Thamnodynastes strigilis (NCN) Prey. Herpetological Review, 37: 235.

Avila, L.J.; Martinez, L.E. \& Morando, M. 2013. Checklist of lizards and amphisbaenians of Argentina: an update. Zootaxa, 3616: 201-238.

Ávila-Pires, T.C.S. 1995. Lizards of Brazilian Amazonia (Reptilia: Squamata). Zoologische Verhandelingen, 299: 1-706.

Bailey, J.R.; Thomas, R.A \& da Silva Jr., N.J. 2005. A revision of the South American snake genus Thamnodynastes Wagler, 1830 (Serpentes, Colubridae, Tachymenini). I. Two new species of Thamnodynastes from Central Brazil and adjacent areas, with a redefinition of and neotype designation for Thamnodynastes pallidus (Linnaeus, 1758). Phyllomedusa, 4: 83-101.

Bellini, G.P.; Giraudo, A.R. \& Arzamendia, V. 2014. Comparative ecology of three species of Thamnodynastes (Serpentes, Dipsadidae) in subtropicaltemperate South America. Herpetological Journal, 24: 87-96.

Bergallo, H.G.; Rocha, C.F.D.; Alves, M.A.S. \& van Sluys, M. 2000. A fauna ameaçada de extinção do Estado do Rio de Janeiro. Ed. UERJ, Rio de Janeiro. $166 \mathrm{p}$.

Bittencourt-Silva, G.B. \& Silva, H.R. 2013. Insular anurans (Amphibia: Anura) of the coast of Rio de Janeiro, Southeast, Brazil. Check List, 9: 225-234.

Boquimpani-Freitas, L.; Marra, R.V.; van Sluys, M. \& Rocha, C.F.D. 2007. Temporal niche of acoustic activity in anurans: interspecific and seasonal variation in a neotropical assemblage from south-eastern Brazil. Amphibia-Reptilia, 28: 269-276.

Boquimpani-Freitas, L.; Rocha, C.F.D. \& van Sluys, M. 2002. Ecology of the Horned Leaf-Frog, Proceratophrys appendiculata (Leptodactylidae), in an insular Atlantic Rain-Forest Area of Southeastern Brazil. Journal of Herpetology, 36: 318-322.

Boquimpani-Freitas, L.; Vrcibradic, D.; Vicente, J.J.; Bursey, C.R.; Rocha, C.F.D. $\&$ van Sluys, M. 2001. Helminths of the horned leaf frog, Proceratophrys appendiculata, from southeastern Brazil. Journal of Helminthology, 75: 233-236.

Borges-Junior, V.N.T.; Gil, L.0.; Rocha, C.F.D. \& van Sluys, M. 2007. Scinax trapicheiroi (NCN). Predation. Herpetological Review, 38: 196.

Bursey, C.R.; Vrcibradic, D.; Hatano, F.H. \& Rocha, C.F.D. 2006. New genus, new species of Acanthocephala (Echinorhynchidae) from the brazilian frog Hylodes phyllodes (Anura: Leptodactylidae). Journal of Parasitology, 92: 353-356.

Cacciali, P. \& Scott, N.J. 2015. Key to the Ophiodes (Squamata: Sauria: Diploglossidae) of Paraguay with the description of a new species. Zootaxa, 3980: 42-50.

Callado, C.H.; Barros, A.A.M; Ribas, L.A.; Albarello, N.; Gagliardi, R. \& Jascone, CE. 2009. Flora e cobertura vegetal. In: Bastos, M. \& Callado, C.H. (Orgs.). 0 Ambiente da llha Grande. Rio de Janeiro, UERJ/CEADS. p. 91-161.

Canedo, C. \& Pombal, J.P., Jr. 2007. Two new species of torrent frog of the genus Hylodes (Anura, Hylodidae) with nuptial thumb tubercles. Herpetologica, 63: 224-235.
Carvalho, A.L.G. 2013. On the distribution and conservation of the South American lizard genus Tropidurus Wied-Neuwied, 1825 (Squamata: Tropiduridae). Zootaxa, 3640: 42-56.

Carvalho, A.L.G. 2016. Three new species of the Tropidurus spinulosus group (Squamata: Tropiduridae) from eastern Paraguay. American Museum Novitates, 3853: 1-44.

Carvalho-e-Silva, A.M.P.T. \& Carvalho-e-Silva, S.P. 2005. New species of the Hyla albofrenata group, from the states of Rio de Janeiro and São Paulo, Brazil (Anura, Hylidae). Journal of Herpetology, 39: 73-81.

Costa, H.C. \& Bérnils, R.S. 2015. Répteis brasileiros: Lista de espécies 2015. Herpetologia Brasileira, 4: 75-93.

Crump, M.L. \& Scott Jr., N.J. 1994. Visual encounter surveys. In: Heyer, W.R.; Donnelly, M.A.; McDiarmid, R.W.; Hayek, L.A.C. \& Foster, M.S. (Eds.). Measuring and Monitoring Biological Diversity, Standard Methods for Amphibians. Washington DC, Smithsonian Institution Press. p. 84-92.

Dorigo, T.A.; Vrcibradic, D.; Borges-Junior, V.N.T. \& Rocha C.B.D. 2014. New records of anuran predation by snakes of the genus Thamnodynastes Wagler, 1830 (Colubridae: Dipsadinae) in the Atlantic rainforest of southeastern Brazil. Herpetology Notes, 7: 261-264.

Esbérard, C.E.L.; Jordão-Nogueira, T.; Luz, J.L.; Melo, G.G.S.; Mangolin, R.; Jucá, N.; Raíces, D.S.L.; Enrici, M.C. \& Bergallo, H.G. 2006. Morcegos da Illha Grande, Angra dos Reis, RJ, Sudeste do Brasil. Revista Brasileira de Zoociências, 8: 151-157.

Fatorelli, P.; Costa, P.N.; Laia, R.C.; Almeida-Santos, M.; van Sluys, M. \& Rocha, C.F.D. 2010. Description, microhabitat and temporal distribution of the tadpole of Proceratophrys tupinamba Prado \& Pombal, 2008. Zootaxa, 2684: 57-62.

Franco, F.L. \& Ferreira, T.G. 2002. Descrição de uma nova espécie de Thamnodynastes Wagler, 1830 (Serpentes, Colubridae) do nordeste brasileiro, com comentários sobre o gênero. Phyllomedusa, 1: 57-74.

Franco, F.L.; Trevine, V.C.; Montingelli, G.G. \& Zaher, H. 2017. A new species of Thamnodynastes from the open areas of central and northeastern Brazil (Serpentes: Dipsadidae: Tachymenini). Salamandra, 53: 339-350.

Frost, D.R. 2017. Amphibian Species of the World: an Online Reference. Version 6.0 (10/05/2017). Electronic Database available at: http:// research.amnh.org/vz/herpetology/amphibia/index.php. American Museum of Natural History, New York, USA.

Gama, S.V.G.; Silva, L.G.A.E. \& Salgado, M.C. 2009. Geologia, relevo e solos. In: Bastos, M. \& Callado, C.H. (Orgs.). 0 Ambiente da Ilha Grande. Rio de Janeiro, UERJ/CEADS. p. 21-64.

Goyannes-Araújo, P.; Siqueira, C.C.; Laia, R.C.; Almeida-Santos, M.; Guedes, D.M. \& Rocha, C.F.D. 2015. Anuran species distribution along an elevational gradient and seasonal comparisons of leaf litter frogs in an Atlantic Rainforest area of southeastern Brazil. Herpetological Journal, 25: 75-81.

Haddad, C.F.B. 2008. Uma análise da Lista Brasileira de Anfíbios Ameaçados de Extinção. In: Machado, A.B.M.; Drummond, G.M. \& Paglia, A.P. (Eds.). Livro vermelho da fauna brasileira ameaçada de extinção. Belo Horizonte, Fundação Biodiversitas. p. 286-230.

Haddad, C.F.B.; Toledo, L.F.; Prado, C.P.A.; Loebmann, D.; Gasparini, J.L. \& Sazima, I. 2013. Guia dos anfibios da Mata Atlântica - diversidade e biologia. São Paulo, Anolis Books. 542 pp.

Hatano, F.H.; Gettinger, D.; van Sluys, M. \& Rocha, C.F.D. 2007. Parasitism of Hylodes phyllodes (Anura: Cycloramphidae) by Hannemania sp. (Acari: Trombiculidae) in an area of Atlantic Forest, Ilha Grande, southeastern Brazil. Parasite, 14: 107-112.

Hatano, F.H.; Rocha, C.F.D. \& van Sluys, M. 2002. Environmental factors affecting calling activity of a tropical diurnal frog (Hylodes phyllodes: Leptodactylidae). Journal of Herpetolology, 36: 314-318.

Heyer, W.R. 1983. Variation and systematics of frogs of the genus Cycloramphus (Amphibia, Leptodactylidae). Arquivos de Zoologia, 30: 235-339. 
Instituto Estadual do Ambiente (INEA). 2013. Instituto Estadual do Ambiente. Parque Estadual da Illha Grande: plano de manejo (fase 2)/resumo executivo/ Instituto Estadual do Ambiente. Rio de Janeiro, INEA. 98p. il. Mapas.

Jackson, J.F. 1978. Differentiation in the genera Enyalius and Strobilurus (Iguanidae): Implications for Pleistocene climatic changes in eastern Brazil. Arquivos de Zoologia, 30: 1-79.

Jaeger, R. \& Inger, R.F. 1994. Standard techniques for inventory and monitoring: Quadrat sampling. In: Heyer, W.R.; Donnelly, M.A.; McDiarmid, R.W.; Hayek, L.A.C. \& Foster, M.S. (Eds.). Measuring and monitoring biological diversity, standard methods for Amphibians. Washington DC, Smithsonian Institution Press. p. 97-102.

Laia, R.C.; Fatorelli, P.; Hatano, F.H. \& Rocha, C.F.D. 2010. Tadpole of Hylodes fredi (Anura; Hylodidae), a frog endemic to an Atlantic Forest island (Ilha Grande, Rio de Janeiro State), Brazil. Zootaxa, 2640: 62-64.

Marra, R.V.; van Sluys, M. \& Rocha, C.F.D. 2004. Food habits of Eleutherodactylus parvus (Anura: Leptodactylidae) at an Atlantic Rainforest area, Southeastern Brazil. Herpetological Review, 35: 135-137.

Martins, M. \& Molina, F.B. 2008. Panorama geral dos répteis ameaçados do Brasil. In: Machado, A.B.M.; Drummond, G.M. \& Paglia, A.P. (Eds.). Livro vermelho da fauna brasileira ameaçada de extinção. Belo Horizonte, Fundação Biodiversitas. p. 327-334.

Mittermeier, R.A.; W.R. Turner; F.W. Larsen; T.M. Brooks \& C. Gascon. 2011. Global biodiversity conservation: the critical role of hotspots. In: Zachos, F.E. \& Habel, J.C. (Eds.). Biodiversity Hotspots. London, Springer Publishers. p. 3-22.

Montechiaro, L.; Kaefer, I.L.; Quadros, F.C. \& Cechin, S. 2011. Feeding habits and reproductive biology of the glass lizard Ophiodes of. striatus from subtropical Brazil. North-Western Journal of Zoology, 7: 63-71.

Peloso, P.L.V.; Sturaro, M.J.; Forlani, M.C.; Gaucher, P.; Motta, A.P. \& Wheeler, W.C. 2014. Phylogeny, taxonomic revision, and character evolution of the genera Chiasmocleis and Syncope (Anura, Microhylidae) in Amazonia, with descriptions of three new species. Bulletin of the American Museum of Natural History, 386: 1-96.

Pereira, L.; Torres, E.M.; Silva, H.S. \& Geise, L. 2001. Non-volant mammals of Ilha Grande and adjacent areas in southern Rio de Janeiro state, Brazil. Boletim do Museu Nacional, nova série, Zoologia, 459: 1-15.

Pizzatto, L. 2005. Reproductive biology of the "glass snake" Ophiodes fragilis (Squamata: Anguidae) in South-East Brazil. Herpetological Journal, 15: 9-13.

Prado, G.M. \& Pombal Jr., J.P. 2008. Espécies de Proceratophrys MirandaRibeiro, 1920 com apêndices palpebrais (Anura; Cycloramphidae). Arquivos de Zoologia, 39: 1-85.

Rico, M.; Rocha, C.F.D.; Borges JR., V.N.T. \& van Sluys, M. 2004. Breeding ecology of Scinax trapicheiroi (Anura, Hylidae) at a creek in the Atlantic Rainforest of Ilha Grande, southeastern Brazil. Amphibia-Reptilia, 25: 277-286.

Rocha, C.F.D. \& Bergallo, H.G. 2011. Occurrence and distribution of the exotic lizard Hemidactylus mabouia Moreau de Jonnès, 1818 in Ilha Grande, RJ, Brazil. Brazilian Journal of Biology, 71: 447-450.

Rocha, C.F.D. \& van Sluys, M. 2006. New records of reptiles from Ilha Grande Island, in Rio de Janeiro State, Brazil. Herpetological Review, 37: 112-114.

Rocha, C.F.D. \& Vrcibradic, D. 2003. Nematode assemblages of some insular and continental lizard hosts of the genus Mabuya Fitzinger (Reptilia, Scincidae) along the eastern Brazilian coast. Revista Brasileira de Zoologia, 20: 755-759.

Rocha, C.F.D.; Anjos, L.A. \& Bergallo, H.G. 2011. Conquering Brazil: the invasion by the exotic gekkonid lizard Hemidactylus mabouia (Squamata) in Brazilian natural environments. Zoologia, 28: 747-754.

Rocha, C.F.D.; Bergallo, H.G.; Alves, M.A.S; van Sluys, M.; Mazzoni, R. \& Santos, S.B. 2009. Fauna de ambientes interiores. In: Bastos, M. \& Callado,
C.H. (Orgs.). 0 Ambiente da Ilha Grande. Rio de Janeiro, UERJ/CEADS. p. $163-246$.

Rocha, C.F.D.; Bergallo, H.G.; Pombal Jr., J.P.; Geise, L.; van Sluys, M.; Fernandes, R. \& Caramaschi, U. 2004a. Fauna de anfíbios, répteis e mamíferos do estado do Rio de Janeiro, Sudeste do Brasil. Publicações Avulsas do Museu Nacional, 104: 1-24.

Rocha, C.F.D.; van Luys, M.; Alves, M.A.S.; Bergallo, H.G. \& Vrcibradic, D. 2000. Activity of leaf litter frogs: when should frogs be sampled? Journal of Herpetology, 34: 285-287.

Rocha, C.F.D.; van Sluys, M. \& Hatano, F.H. 1997. Geographic distribution. Hylodes phyllodes (Leaf frog). Herpetological Review, 28: 208.

Rocha, C.F.D.; van Sluys, M.; Alves, M.A.S.; Bergallo, H.G. \& Vrcibradic, D. 2001. Estimates of forest floor litter frog communities: a comparison of two methods. Austral Ecology, 26: 14-21.

Rocha, C.F.D.; van Sluys, M.; Bergallo, H.G. \& Alves, M.A.S. 2002. Microhabitat use and orientation to water flow direction by tadpoles of the Leptodactylid frog Thoropa miliaris in Southeastern Brazil. Journal of Herpetology, 36: 98-100.

Rocha, C.F.D.; van Sluys, M.; Bergallo, H.G.; Alves, M.A.S. \& Vrcibradic, D. 1998. Zachaenus parvulus (Leaf Frog). Defensive behavior and color pattern. Herpetological Review, 29: 232-233.

Rocha, C.F.D.; Vrcibradic, D. \& van Sluys, M. 1999. Chironius multiventris foveatus (NCN). Prey. Herpetological Review, 30: 99-100.

Rocha, C.F.D.; Vrcibradic, D. \& van Sluys, M. 2004b. Diet of the lizard Mabuya agilis (Sauria; Scincidae) in an insular habitat (Ilha Grande, RJ, Brazil). Brazilian Journal of Biology, 64: 135-139.

Segalla, M.V.; Caramaschi, U.; Cruz, C.A.G; Grant, T.; Haddad, C.F.B; Garcia, P.C.A.; Berneck, B.V.M. \& Langone, J.A. 2016. Brazilian Amphibians: List of Species. Herpetologia Brasileira, 5: 34-46.

Siqueira, C.C.; van Sluys, M.; Ariani, C.V. \& Rocha, C.F.D. 2006a. Feeding Ecology of Thoropa miliaris (Anura, Cycloramphidae) in four areas of Atlantic Rain Forest, southeastern Brazil. Journal of Herpetology, 40: 520-525.

Siqueira, C.C.; Ariani, C.V.; van Sluys, M. \& Rocha, C.F.D. 2006b. Thoropa miliaris (Rock River Frog). Tadpole predation. Herpetological Review, 37: 451-452.

Stuart, S.N.; Hoffmann, M.; Chanson, J.S.; Cox, N.A.; Berridge, R.J.; Ramani, P.; \& Young, B.E. 2008. Threatened Amphibians of the World. Barcelona, Lynx Edicions. $758 \mathrm{p}$.

Telles, F.B.S.; Militão, C.M; Bergallo, H.G. \& Rocha, C.F.D. 2015. Invasion of the alien gecko Hemidactylus mabouia (Moureau de Jonnès, 1818) in a natural habitat at Praia do Sul Biological Reserve, Ilha Grande, RJ, Brazil. Brazilian Journal of Biology, 75: 768-770.

Tonini, J.F.R.; Forlani, M.C. \& de Sá, R.0. 2014. A new species of Chiasmocleis (Microhylidae, Gastrophryninae) from the Atlantic Forest of Espírito Santo State, Brazil. ZooKeys, 428: 109-132.

van Sluys, M. \& Rocha, C.F.D. 1999. Tupinambis merianae (Common Tegu). Activity. Herpetological Review, 30: 42-43.

van Sluys, M.; Ferreira, V.M. \& Rocha, C.F.D. 2004. Natural history of Enyalius brasiliensis (Lesson, 1828) (Leiosauridae) from an Atlantic Forest of southeastern Brazil. Brazilian Journal of Biology, 64: 353-356.

van Sluys, M.; Marra, R.V.; Boquimpani-Freitas, L. \& Rocha, C.F.D. 2012. Environmental factors affecting calling behavior of sympatric frog species at an Atlantic Rain Forest area, Southeastern Brazil. Journal of Herpetology, 46: 41-46.

van Sluys, M.; Rico, M. \& Rocha, C.F.D. 2006. Seasonal and hourly patterns of reproductive activity in Scinax trapicheiroi (Anura, Hylidae), Rio de Janeiro State, south-eastern Brazil. Herpetological Journal, 16: 15-20.

van Sluys, M.; Rocha, C.F.D. \& Souza, M.B. 2001. Ecology of the Leptodactylid litter frog Zachaenus parvulus in Atlantic Rainforest of southeastern Brazil. Journal of Herpetolology, 35: 322-325. 
van Sluys, M.; Vrcibradic, D.; Alves, M.A.S.; Bergallo, H.G. \& Rocha, C.F.D. 2007. Ecological parameters of the leaf-litter frog community of an Atlantic Rainforest area at Ilha Grande, Rio de Janeiro state, Brazil. Austral Ecology, 32: 254-260.

Vrcibradic, D.; Almeida-Gomes, M.; van Sluys, M. \& Rocha, C.F.D. 2008. Amphibia, Anura, Hylodes charadranaetes, Ischnochnema octavioi and Euparkerella cochranae: Distribution extension. Check List, 4: 103-106.

Vrcibradic, D.; Mausfeld-Lafdhiya, P. \& Rocha, C.F.D. 2006. Molecular phylogeny of Brazilian Mabuya (Reptilia, Squamata, Scincidae) of the agilis/caissara/heathi complex. Herpetological Journal, 16: 83-91.

Vrcibradic, D.; Rocha, C.F.D.; Kiefer, M.C.; Hatano, F.H.; Fontes, A.F.; AlmeidaGomes, M.; Siqueira, C.C.; Pontes, J.A.; Borges-Junior, V.N.T.; Gil, L.0.; Klaion, T.; Rubião, E.C.N. \& van Sluys, M. 2011. Herpetofauna, Estação
Ecológica Estadual do Paraíso, state of Rio de Janeiro, southeastern Brazil. Check List, 7: 745-749.

Vuilleumier, F. 1998. In Memoriam: Helmut Sick, 1910-1991. The Auk, 115: 470-472.

Winck, G.R. 2012. Comunidades de lagartosnos remanescentes derestingado Estado do Rio de Janeiro: Riqueza, diversidade e onde estão as espécies endêmicas e ameaçadas de extinção. Tese de Doutorado, Programa de Pós Graduação em Ecologia e Evolução - Universidade do Estado do Rio de Janeiro.

Winck, G.R.; Vrcibradic, D.; Telles, F.B.S.; Borges-Júnior, V.N.T.; van Sluys, M. \& Rocha, C.F.D. 2011. Squamata, Iguania, Anolis punctatus Daudin, 1802 and Tropidurus torquatus (Wied, 1820): Distribution extension and new records for Illha Grande, state of Rio de Janeiro, southeastern Brazil. Check List, 7: 270-271.

\section{APPENDIX 1}

\section{Voucher specimens of taxa representing new or previously unvouchered records for Ilha Grande.}

\section{Amphibia:}

Ischnocnema bolbodactyla: MNRJ 89141-42

Leptodactylus latrans: MNRJ 31743, MNRJ 31748-49, MNRJ 46869, MNRJ 68698-700, MNRJ 75815

\section{Reptilia:}

Boa constrictor: ZUFRJ 800

Corallus hortulanus: IBSP 28941, IBSP 30056, IBSP 30232, IBSP 30394, IBSP 30449, IBSP 30610, IBSP 43770, MNRJ 8868, MNRJ 24212

Dipsas albifrons: IBSP 27608

Dipsas alternans: MNRJ 8060

Echinantera cephalostriata: MNRJ 19183

Erythrolamprus aesculapii: MNRJ 4936

Liotyphlops wilderi: MNRJ 7853

Mastigodryas bifossatus: MNRJ 8404

Ophiodes cf. striatus: MNRJ 16059

Philodryas olfersii: IBSP 27093, MNRJ 8440

Xenodon merremi: MNRJ 8161 